\title{
A Teacher's Beliefs in Grammar and Her Teaching Practices: A Case Study of One Experienced EFL Teacher in A High School in Surakarta
}

\author{
Dani Puspitasari, Gunarso Susilohadi, Dewi Sri Wahyuni \\ English Education Department \\ Teacher Training and Education Faculty \\ Sebelas Maret University of Surakarta
}

\author{
Email:puspitadani@gmail.com
}

\begin{abstract}
Borg (2009) states that there is a relationship between people's action and their belief and knowledge. It makes educational researchers take more concern with a similar phenomenon which occurs in teaching learning process. Borg claims that 'teachers' mental lives play a role in their instructional practices'. This qualitative research reports a case study of teacher's beliefs in grammar and her grammar teaching practice in SMA Negeri 5 Surakarta. The data were collected by in-depth interview with the teacher, in-depth interview with students, and passive classroom observation. The data were analyzed by qualitative data analysis proposed by Miles and Huberman (1994). The result of the research indicates that the teacher's beliefs of grammar and teaching grammar influence her grammar teaching practices.
\end{abstract}

Keywords: teacher's beliefs, grammar, teaching practice

\section{INTRODUCTION}

Belief plays central roles in someone's decision. People do something because they think what they are going to do is true. This is in line with what Uztosun (2013) claims "belief as the best indicators of the decision made by individual in the course of their lifetime". In other word, people behave because something that bears in their mind leads them to do so.

Teik (2011) sees that this same phenomenon also occurs in the classroom. He states "teachers play a central role in facilitating students' mastery of the English language". We can say that students' ability is strongly influenced by teachers' practices in the classroom and the teachers' classroom practices are influenced by their belief, therefore there is a link between language mastery and their teachers' beliefs.

Borg (2009) suggests that
understanding teachers, cognition is important. He convinces that in attempting to understand the teachers, we need to consider the psychological process that controls the sense of their work. Moreover, on his previous journal Borg (2003: 81) puts his idea on this discussion by saying "teachers are active, thinking decisionmakers who make instructional choices by drawing on complex, practically-oriented, personalized, and context-sensitive networks of knowledge, thoughts, and beliefs". He considers teachers' belief takes significant role on their teaching practices. In the line with Borg, Farrel and Bernis (2013: 164) give positive support to his notion. Based on 
their case study of ESL teachers' beliefs and teaching practices, they state that that all teachers have their own belief about teaching and learning.

Based on the background study above, the researcher conducted research about teacher's beliefs of teaching grammar and grammar teaching practices. The objectives of the study are: (1) to find out and describe about teacher's belief; (2) to find out and describe the factors that influence teacher's belief; (3) to find out and describe the relationship between the teachers' belief in grammar to the grammar teaching practice.

\section{RESEARCH METHODS}

The research is qualitative case study. Wong \& Barrea-Marlys (2012) put their idea that qualitative study is best used for conducting classroom observation which can allow us to understand teachers' voice about the grammar instruction through interview.

The research was conducted in a high school in Surakarta. The reason of choosing the school was because of the hospitability of the school and also the openness of the teacher to the research inquiries. The teacher who was observed in the research was an experienced teacher. The term 'experienced' is based on the Farrel and Bennis's (2013) idea. They define the term 'experienced' as having more than three years of teaching experience (pg. 165). The research was done in about five months; two months for composing the proposal, two months for gathering the data, and one month for data analysis. The data were collected by indepth interviews with the teacher and students and passive participant observation. During the research, good rapport with the teacher and students was established by the researcher in order to gather the data. The data was analyzed using qualitative data analysis which is proposed by Miles and Huberman (1994) which consist of data reduction, data display, and conclusion drawing and verification.

\section{RESEARCH FINDINGS AND DISCUSSIONS}

The findings which presented are divided into three parts. They are findings about the teacher's beliefs of grammar and teaching grammar; the sources of the teacher's beliefs; and the grammar teaching practices.

The first part is about the teacher's belief of grammar. The pedagogical issues that arose during the interviews are beliefs about grammar and beliefs about teaching grammar. The teacher had abiding paradigm with regard to grammar and its teaching. The teacher viewed that grammar is rule of word order which covers form, use, and usage. She also maintained that grammar has significant role in language learning and she convinced without grammar students were not able to learn English. Her view related to grammar and the importance of grammar shapes her beliefs about teaching grammar. As Nazari and Allahnyar (2012) conclude on their journal, teachers who have more knowledge about grammar (KAG) will have wider judgment related to grammar and its teaching.

The teacher had admirable opinion about teaching grammar; she stated that the goal of teaching grammar is to make all students understand the rules that are used in English. She also explained that grammar consists of complex rules which should be learnt and it is a must for her to make the students comprehend all the rules. The teacher also pointed out that teaching grammar covers the understanding of word order, vocabulary mastery, and correct pronunciation. 
Related to the grammar curriculum, the teacher deemed that the national curriculum which applies communicative approach is less concerned of grammar. She believed that learning English should be accompanied by teaching grammar. She stated that the objectives of learning English cannot be achieved without formal teaching grammar, if not the goal cannot be fulfilled.

Regarding to the grammar lesson plan, the teacher viewed that one lesson plan cannot be implemented to all students in the same grade. She believed that the flexibility of lesson plan was important in her grammar class. It is because she said every learner needed different treatment.

Regarding to the error correction, the teacher believed that error correction is best done by the learners themselves. She was convinced that it was good if they were able to recognize their mistakes they made. The teacher believed that accuracy is more important than fluency; she strived her principle in order to make students are able to use grammar in appropriate ways.

Another related issue regarding with grammar teaching is grammar material. The teacher believed that grammar material should be interesting. She deemed that the grammar materials which are provided by the current communicative text book are not sufficient to cover the demand of grammar teaching.

According to Larsen-Freeman (2001), the teacher has fulfilled the requirement of teacher's role; as she mentions that teachers have to identify their learners' obstacle in learning English. The teacher believed that analyzing her students' competence was essential for her to determine the approach of her teaching. She maintained that each classes required different approach. The teacher also viewed that the teaching instruction should be done explicitly. She also had outstanding belief that teaching transforms not only knowledge but also values.

The second term discusses the source of the teacher's beliefs. The research reveals that the teacher's beliefs are influenced by some factors. They are her experience as a language learner, her experience as a language teacher, the curriculum, the students' condition, discussion with other teacher, and preferences. The teacher' experience as language a learner is the wellspring of her teaching decision. As she explained during the interviews that when she was learner she used to be drilled and memorized the grammar rule, and now she is convinced that grammar should be taught so. This is in line with Farrel (1999) who observes five pre-service teachers in Singapore; he reports that all the pre-service teachers' beliefs are impacted by their past experience.

The teacher's experience as a language teacher also shaped her belief toward teaching grammar, as she had been teaching for fifteen years. She stated that her teaching experience made her realized that something should and should not be done in her class. Borg (2003) also indicates that teachers' beliefs can be derived from their accumulation of teaching experiences ( $p$. 95). Current curriculum also contributed to her belief toward grammar teaching. She considered the demand of communicative competence cannot be achieved due to the lack of grammar focus. The condition makes her convinced that grammar should be taught formally in her language class.

Understanding her learners' character also shaped her belief toward grammar teaching. She recognized her learners were in the intermediate level and because of that she decided that she should provide simple material and teach grammar explicitly. She identified that the learners will not do the task if they are not given 
clear instruction. Besides understanding the learner's condition, discussion with fellow teacher also influenced her decision toward grammar material.

Some preferences also contribute the teacher's view toward pedagogical issues. She acknowledged that her personal desire in grammar was the reason why she is passionate in teaching grammar. Besides her interest of teaching grammar, her personality also contributes on her beliefs. Wu (2006) also suggests teachers' personality can affect their beliefs. The teacher also stated that reading psychology book about children cognition affected to her way of teaching. She confessed that she cannot rebuke or yell in her classroom even the learners aggravated her. Rather than pushed her learners with anger when they disobeyed, she preferred to analyze the reasons behind their behavior. This is the reasons why she strived to make good rapport with her students.

Another tendency which influences her beliefs is the teacher self-reflection. The teacher conducted her reflective teaching by asking her students' opinion about her teaching practice. She gave them the opportunity to comment on her grammar class. Even these students' notion irritated her but she accepts it as a process of being a good teacher. In this term, the teacher's welcome to critic plays significant role into her beliefs about teaching. Because of her self-reflection she can make better teaching and help her to correct her teaching. Farrell and Bernis (2013) state when teachers can be active reflectors of their classroom' occurrence, they can get better understanding in discovering any gap between what they teach and what theirs students learn.

The last part discusses the teacher's grammar teaching practices. During the classroom observation the researcher found that the teacher used some approaches in the classroom. The teacher used the inductive or non-directive teaching approach on active class, while on the less-active class the teacher used deductive or directive teaching approach. This is the result of her belief that she has to make the students comprehend the grammar rule. By her teaching experiences, the teacher found that each class required different approach, thus she combined some approaches in her classroom practices to meet the objectives of her teaching grammar. The teacher also applied some strategies in her grammar explanation such as; writing explanations of grammar rule on the white board, eliciting the grammar rules from examples, and providing as many examples as possible from daily life activities in teaching structures

Related to the grammar curriculum the teacher deems that the current curriculum is lack of grammar focus. Because she had privilege to establish her own grammar curriculum in her extracurricular English class; she revised the national curriculum to be more focus on grammar. More focus on grammar means that the grammar drilling is always done in class for every single meeting. Students have to memorize the rules of English structures and the teacher regularly gives them some exercises about tenses. They are given some exercises to convert some sentences from one tense to other tenses or memorize the irregular verbs. These activities are the reflection of her beliefs; she states that grammar plays significant role in students' English mastery and she convinces without grammar students are not able to learn English in appropriate way. The teacher's belief towards grammar influences her curriculum and lesson plans. Therefore, grammar explanation and drilling are always found in her teaching practices. 
Related to the grammar material, the researcher found that the teacher determined the material in accordance with the students' interest to alter their apprehension that grammar was difficult. This is the consideration of her beliefs that grammar material should be interesting. The teacher deems that the current textbook cannot cover the demand of grammar teaching and her teaching practice reveals that her belief is reflected. She develops her grammar material in order to fulfill the demand of teaching grammar and to create interesting material. Besides regarding the interesting material, the teacher also concerns with the time constrain, therefore to solve the problem related with time constrain she always gave her students task as homework. Similar findings from Farrell \& Lim (2005) and Farrell \& Bennis (2013) reveal that experienced teacher pay attention regarding time constrain in their classroom practices.

Regarding the teaching techniques, the teacher applied the techniques test teach-practice. The first is test, teacher test the students in order to know their understanding of grammar. The second is teaching, after giving test to measure the students' understanding she teaches them the English structures. Last, she gave the students some practice. The teacher gave practice in three ways. First she gave classical practice, then group practice, and last individual practice. The teacher emphasized the individual practice not to all students; she just did this to some students who had problem in grammar. This is worthy to note that the teacher recognized which students need special treatment and not. As she mentioned before, the teacher believed that she had to make sure that all students understand the grammar rule. The teacher's teaching technique is congruent with her belief.
Regarding with students' error and mistake, the teacher used two techniques in conducting error and mistake correction. First, she gave opportunity to students to correct their friend's mistakes. The teacher let the students to make peer correction and she encouraged them to directly correct their friend's mistake. Second, the teacher overlooked the mistake and error that students' produced. The second phenomenon occurred on less-active class. She overlooked the error by re-stating their error or showing one error and gives examples of the correct one. This happened because the students did not recognize their error.

How the teacher corrects her
students' error and mistake is a consideration of her beliefs. She believes that accuracy is more important that fluency. Therefore, she applies the two techniques in order to make the students understand. The teacher also deems that the error correction is best done by the learners themselves hence she gives opportunities to them to correct their error. The flexibility of the teacher in conducting error correction shows that she strives to make sure the students understand the grammar rules. The researcher concludes that the teacher's beliefs about error correction can be reflected on her classroom practices.

Related to the vocabulary drilling, the teacher always gave her students a bundle of paper which consists of irregular verb and after they got the paper they should memorize the entire irregular verb then they were given test to check their comprehension. This teaching practice is the reflection of the teacher's belief. She states that vocabulary mastery is the main part of her grammar teaching. Therefore, she conducts the vocabulary drilling in her grammar class. 
The facts that the teacher taught with discipline are derived from students' opinions. The researcher conducted interviews with ten students from different class. All students confessed that the teacher used firm discipline in her grammar class. One of the discipline manner is students are not allowed to come late in attending class, if so they should have reason and expressed it in English. Students also reported that in the submitting assignment they should be punctuated if not they will get punishment. These teaching practices is the teacher's consideration that teaching is not only transform the knowledge but also values.

Based on the findings we can take summary that there is a relation between the teacher's beliefs toward her grammar teaching practices. The teacher views that grammar is a set of rules and without grammar students are not able to use English in appropriate way. Thus, she always formally teaches grammar in her classroom. The teacher's beliefs toward grammar and teaching grammar are reflected in her teaching practices. In spite of the teacher's beliefs are congruent with her teaching practices, some changes also occurs.

Richard, Gallo, and Renandya (2001) regard that change as major dimension in teachers' professional lives which all teachers are expected to have positive change in the need of being thoughtful. They suggest that changes in teachers' practices are the results of changes of their beliefs. This research reveals that teacher change is mostly influenced by her students. This is not hard to predict that learners provide change on her beliefs, since they are together all the time.

Besides the learners' engagements on class, the learners' competence also the reason of teacher changes her teaching practices. The teacher's change of her teaching practices occurs when she is dealing with error correction. The teacher believes that error correction is best done by the learners themselves, but on the lessactive class this belief cannot be done. Thus, the teacher overlooks the errors or mistakes when they occur. The same phenomenon also revealed by Farrell \& Bernis (2013) who explored between teachers' belief and grammar instructional practices of two teachers, experienced and novice, they report that experienced teacher's beliefs diverged from their practices because of their ability to react toward the realities of the classroom.

Overall, result of this descriptive case study suggests that, in teaching grammar, the teacher's beliefs of grammar and its teaching give influences into her teaching practices. This research is congruent with Farrell \& Lim, 2005; Al-siyabi, 2009; as they report in their research that teacher's belief influences to the teacher's teaching practice and not congruent with Ezzi, 2012; Uztosun, 2013; Phipps \& Borg, 2009; as they report in their research that teacher's belief does not influence to the teacher's teaching practice.

\section{CONCLUSIONS AND SUGGESTIONS}

The research suggests that it is essential for English language teachers to evaluate their beliefs toward grammar and how to teach grammar. The evaluation can be done through some ways, such as reading books and discussion with other language teachers.

Policy maker in school, headmaster, has to facilitate English language teachers with books about grammar and grammar teaching, thus they can get more knowledge about how grammar should be taught in their classes.

Further researches related to these issues are required to get deeper understanding of teachers' cognition 
especially in Indonesian context. Exploring and understanding the reasons underlying teachers' beliefs are needed to improve the quality of English teaching. Moreover, it is worth to consider another tension which is related to the teacher's cognition, such as teacher's change of their beliefs. Phipps and Borg (2009) also suggest that teacher education program should encourage its studentsto explore their beliefs, their actual practices, and the link among them (p. 388).

\section{BIBLIOGRAPHY}

Al-siyabi, M.M. (2009) Teachers' Practices and Beliefs about Explicit Grammar Teaching, in Simon Borg (Ed.).Researching English Language Teaching and Teacher Development in Oman (pp. 149-156). Ministry of Education: Sultanate of Oman. Retrieved at 10 December 2013 from http://www.moe.gov.com

Borg, S. (2003). Teacher cognition in language teaching: A review of research on what language teachers think, know, believe, and do. Lang. Teach. 36, 81-109. UK: Cambridge University Press. Retrieved 29 Januari 2013 from http://eprints.whiterose.ac.uk/1652/1/ borgs1_Language_Teaching_362.pdf

Borg, S. (2009). Introducing language teacher cognition. Retrieved 29 January $2014 \quad$ from http://www.education.leeds.ac.uk

Ezzi. (2012). Yemeni Teachers' Belief of Grammar Teaching and Classroom Practices. English Language Teaching 5(8), 170-184. Retrieved 1 February $2014 \quad$ from http://www.ccsenet.org

Farrell, T. C., \& Lim, P. C. P. (2005). Conceptions of grammar teaching: A case study of teachers' belief and classroom practices. TESL-EJ, 9 (2). 1-13 retrieved from: http://www.sagepub.com
Farrell, Thomas S.C. \&Bennis, Karren. (2013). Reflecting on ESL Teacher Beliefs and Classroom Practices: A Case Study. RELC Journal 44(22), 163-176. Retrieved 1 February 2014 from www.refflectiveinquiry.com

Larsen-Freeman. (2001). Teaching Grammar. In Celce-Murcia (Ed.).Teaching English as a Second or Foreign Language $3^{\text {rd }}$ Edition ( $p p$. 251-266).USA: Heinle\&Heinle.

Miles \&Huberman.(1994). Qualitative data analysis. California: Sage Publication

Nazari, Ahmad \&Allahyar, Negah. (2012). Grammar Teaching Revisited: EFL teachers between Grammar Abstinence and Formal Grammar Teaching. Australian Journal of Teacher Education, 37(2), 73-87.

Retrieved 10 December 2013 from: http://ro.ecu.edu.au

Phipps \& Borg. 2009. Exploring tension between teacher's grammar teaching beliefs and practices. System 37, 390390. Retrieved 1 February 2014 from: http://www.education.leeds.ac.uk

Richards, Gallo \& Renandya. (2001). Teachers' Belief and the Process of Change. PAC Journal, 1(1), 41-64. Retrived 1 January 2014 from http://aaboori.mshdiau.ac.ir

Teik, Ong Cheng. (2011). Pre-service teachers' beliefs about the teaching and learning of grammar.The English Teacher Vol XL: 27-47. Singapore: Nan yang Technological University. Retrieved 10 December 2013 from: http://www.melta.org.m

Uztosun, Mehmet Sercan. (2013). An Interpretative Study into Elementary School English Teachers' Beliefs and Practices in Turkey. Turkish Online Journal of Qualitative Inquiry, 4(1), 20-32.

Wong \&Barrea-Marlys. (2012). The Role of Grammar in Communicative Language Teaching: An Exploratory 
of Second Language Teacher's perception and Classroom practices. Electronic Journal of Foreign Language Teaching 9(1), 61-

75.Retrieved 1 February 2014 from: http://e-

flt.nus.edu.sg/v9n12012/wongcy.pdf

$\mathrm{Wu}$, Kam-yin. (2006). Teacher beliefs and grammar teaching practices: case studies of four ESL teachers. A thesis of Doctoral Philosophy: The University of Hong Kong. Retrieved 10 December 2013 from: http://hub.hku.hk 